\title{
Kemampuan Metakognisi Mahasiswa Program Studi Pendidikan Matematika FKIP Universitas Jambi
}

\author{
Anggi Syafrudin ${ }^{1}$ \\ ${ }^{1}$ Pascasarjana Pendidikan Matematika Universitas Jambi, \\ Jl. Raden Mattaher No 16, Jambi, Indonesia \\ anggiudin20@gmail.com
}

\begin{abstract}
The purpose of this study was to analyze the metacognitive ability of mathematics education students in each metacognitive component to the process of metacognitive awareness, metacognitive evaluation and metacognitive regulation; Data was collected in the odd semester of the 2019/2020 academic year on 5 subjects of Mathematics Education FKIP Jambi University students. Methods The research uses descriptive qualitative methods. Data were collected through the process of metacognitive awareness, metacognitive evaluation and metacognitive regulation and analyzed descriptively qualitatively. The results showed that students' metacognitive abilities had not developed well, only one student was able to display perfect metacognitive abilities. The average metacognitive ability of students in displaying the process of metacognitive awareness has been seen with students being able to write known in problem solving, students can realize what will be done in solving problems. In presenting metacognitive evaluation which refers to a decision on the effectiveness of student thinking about the strategy chosen to solve the problem, only four students are able to display this ability, and for metacognitive regulation only one student can modify his thinking for problem solving. Based on the results of the study, further research can be carried out on student obstacles in displaying metacognitive abilities by looking at information processing in solving more in-depth problems.
\end{abstract}

Keywords: Metacognition's Abilities, Metacognitive awareness, Metacognitive Evaluation, Metacognitive regulation

\begin{abstract}
Abstrak
Tujuan penelitian ini adalah menganalisis kemampuan metakognisi mahasiswa pendidikan matematika pada setiap komponen metakognisi kepada proses metacognitive awareness, metacognitive evaluation dan metacognitive regulation; Data dikumpulkan pada semester ganjil tahun ajaran 2019/2020 terhadap 5 subjek mahasiswa Pendidikan Matematika FKIP Universitas Jambi. Metode Penelitian menggunakan metode deskriptif kualitatif. Data dikumpulkan melalui proses metacognitive awareness, metacognitive evaluation dan metacognitive regulation dan dianalisis secara deskriptif kualitatif. Hasil penelitian menunjukkan bahwa kemampuan metakognisi mahasiswa belum berkembang baik hanya satu orang mahasiswa yang mampu menampilkan kemampuan metakognisi yang sempurna. Rata-rata kemampuan metakognisi mahasiswa dalam menampilkan proses metacognitive awareness telah terlihat dengan mahasiswa mampu menulis diketahui dalam pemecahan masalah, mahasiswa dapat menyadari apa yang akan dilakukan dalam menyelesaikan soal. Dalam menampilkan metacognitive evaluation yang merujuk pada suatu keputusan dari keefektifan berfikir mahasiswa tentang strategi yang dipilihnya untuk menyelesaikan soal hanya empat mahasiswa yang mampu menampilkan kemampuan tersebut, dan untuk metacognitive regulation hanya satu mahasiswa yang dapat memodifikasi pemikirannya untuk pemecahan masalah. Berdasarkan hasil penelitian dapat dilakukan penelitian lanjutan tentang kendala mahasiswa dalam menampilkan kemampuan metakognisi dengan melihat dari pemprosesan informasi dalam penyelesaian masalah yang lebih mendalam.
\end{abstract}

Kata kunci: Kemampuan Metakognisi Mahasiswa, Metacognitive awareness, Metacognitive Evaluation, Metacognitive regulation

Copyright (c) 2021 Anggi Syafrudin

$\triangle$ Corresponding author: Anggi Syafrudin

Email Address: anggiudin20@gmail.com (J1. Raden Mattaher No 16, Jambi, Indonesia)

Received 17 June 2021, Accepted 26 June 2021, Published 28 June 2021

\section{PENDAHULUAN}

Seorang mahasiswa memerlukan suatu kemampuan yang mampu memberikan cognitive control 
dan self regulatory yang disebut dengan kemampuan metakognisi yang mampu mendukung proses pemecahan masalah matematika. Menurut Desmita (2016:132) bahwa proses tersebut merupakan kemampuan metakognisi dalam menggugah rasa ingin tahu karena kita menggunakan proses kognitif kita untuk merenungkan proses kognitif kita sendiri. Kemampuan metakognisi merupakan kemampuan kognisi tingkat tinggi yang diperlukan untuk manajemen pengetahuan dimana mahasiswa dituntut untuk mengatur tujuan belajarnya sendiri dan menentukan strategi belajar yang sesuai untuk mencapai tujuan pembelajaran. Tanggung jawab mahasiswa juga mencakup monitor proses belajar dan mengubah strategi belajar yang diperlukan (Sastrawati, dkk, 2011). mahsiswa yang terlatih menggunakan strategi metakognisi secara sengaja dalam aktivitas pembelajaran dapat menjadikan dirinya sebagai pembelajar yang mandiri. Panjaitan (2015:19) metakognisi ialah fungsi eksekutif yang mengelola dan mengontrol bagaimana seseorang menggunakan pikirannya dan merupakan proses kognitif yang paling tinggi dan canggih.

Purnaningsih dan Siswono (2014:153) mengatakan bahwa metakognisi merupakan pemahaman seseorang tentang proses berpikirnya sendiri dan pemahaman atau kesadaran seseorang tentang kemampuan kognitifnya sendiri. Sedangkan menurut Desmita (2016:132) metakognisi merupakan suatu proses menggugah rasa ingin tahu karena kita menggunakan proses kognitif kita untuk merenungkan proses kognitif kita sendiri.

Menurut Magiera \& Zawojewski (2011), terdapat hubungan positif antara aktifitas metakognitif dengan pelaksanaan pemecahan masalah. Semakin tinggi tingkat aktivitas metakognitif seseorang, semakin mudah dia memecahkan masalah. Ada tiga aktivitas metakognitif yaitu (1) metacognitive awareness yang berkaitan dengan kesadaran individu dimana mereka berada dalam proses belajar atau dalam proses pemecahan masalah, (2) metacognitive evaluation merujuk pada suatu keputusan dari keefektifan berfikir individu tentang strategi yang dipilihnya, dan (3) metacognitive regulation terjadi ketika individu memodifikasi pemikirannya dalam pemecahan masalah (Wilson \& Clarke, 2004; Magiera \& Zawojewski, 2011).

Metakognisi merupakan pemahaman seseorang tentang proses berpikirnya sendiri dan pemahaman atau kesadaran seseorang tentang kemampuan kognitifnya sendiri. Dalam penelitiannya Syaiful (2011:1) menyatakan "metakognisi memiliki dua komponen, yaitu: (1) pengetahuan metakognitif (metacognitive knowledge) dan (2) keterampilan metakognitif (metacognitive skills). Pengetahuan metakognitif berkaitan dengan pengetahuan deklaratif, pengetahuan prosedural, dan pengetahuan kondisional. Sedangkan keterampilan metakognitif berkaitan dengan keterampilan perencanaan, keterampilan prediksi, keterampilan memonitoring, dan keterampilan evaluasi”. Chairani (2016:59) menyatakan bahwa dua komponen diatas berkaitan dengan proses metakognisi.

Penelitian yang dilakukan oleh Huda, (2018) yang difokuskan pada kegiatan metakognitif mahasiswa yang terjadi pada aktivitas metacognitive awareness, metacognitive evaluation dan metacognitive regulation. Pada penelitian sebelumnya melihat kegagalan proses metakognitif dan penelitian ini hanya melihat proses yang dimana difokuskan kepada proses metacognitive awareness, 
metacognitive evaluation dan metacognitive regulation. Tujuan penelitian ini adalah mendeskripsikan kemampuan metakognisi mahasiswa yang diambil beberapa mahasiswa program studi Pendidikan Matematika FKIP Universitas Jambi.

\section{METODE}

Penelitian ini adalah penelitian deskriptif kualitatif. Menurut Bogdan dan Taylor penelitian kualitatif merupakan sebuah prosedur dasar penelitian yang menghasilkan data deskriptif berupa kata-kata tertulis atau lisan dari orang-orang dan perilaku yang diamati (Moleong, 2013). Pemilihan subjek penelitian dipilih dengan metode purposive sampling. Menurut Patton standar yang digunakan dalam memilih subjek adalah apakah mereka kaya akan informasi (Creeswell, 2012). Sehingga dalam penelitian ini yang menjadi pertimbangan dalam pemilihan subjek yaitu subjek sudah mempelajari materi lingkaran dan subjek yang mampu memberikan informasi sebanyak mungkin. Sampel penelitian merupakan mahasiswa Program Studi Pendidikan Matematika Universitas Jambi semester 3 yang telah mempelajari materi kapita selekta. Jumlah subjek penelitian berjulah 5 orang mahasiswa yang memiliki kemampuan yang beragam.

Teknik pengumpulan data menggunakan soal tes untuk mengukur kemampuan metakognisi dalam indikator metacognitive awareness, metacognitive evaluation dan metacognitive regulation. Teknik analisis data berdasarkan tahapan mereduksi data, menyajikan data dan penarikan kesimpulan atau verifikasi. Mereduksi data artinya merangkum dan memilih hal-hal yang pokok terhadap hasil tes kemampuan metakognisi mahasiswa, setelah di reduksi maka data disajikan berdasarkan kemampuan metakognisi mahasiswa dan terakhir dilakukan penarikan kesimpulan subjek mahasiswa yang dapat memenuhi kemampuan metakognisi dalam indikator metacognitive awareness, metacognitive evaluation dan metacognitive regulation.

Teknik analisis data dalam penelitian ini digambarkan sebagai berikut:

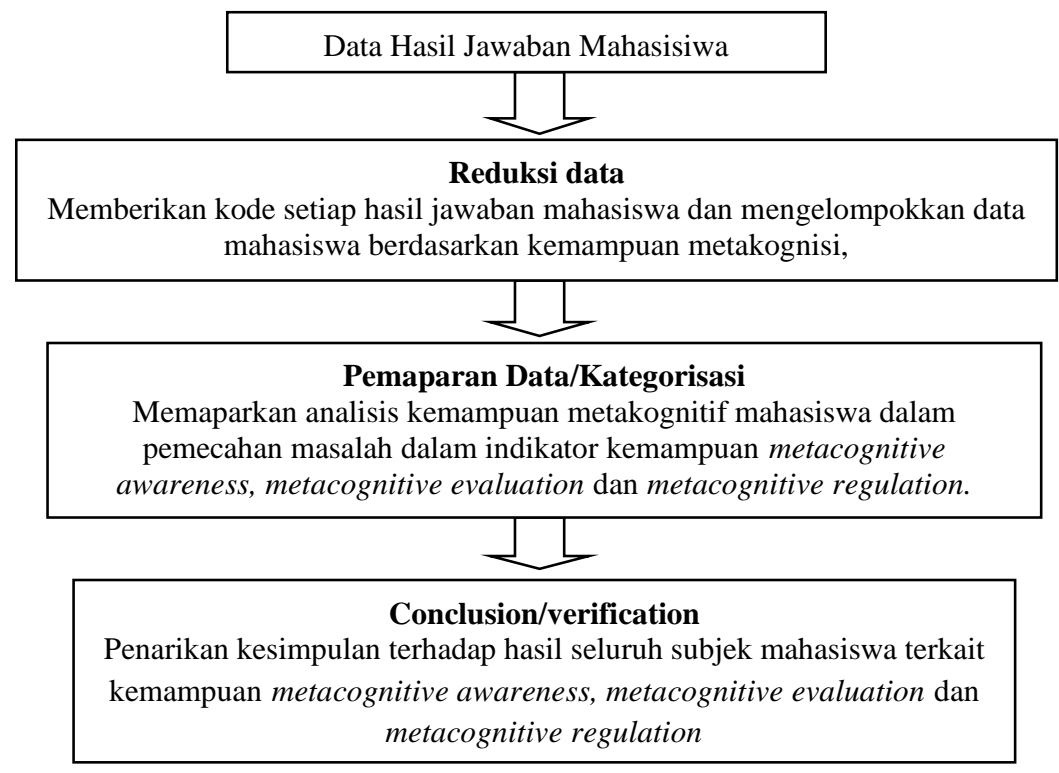

Gambar 1. Diagram Teknik Analisis Data 


\section{HASIL DAN DISKUSI}

\section{Hasil Penelitian}

Secara keseluruhan subjek penelitian mahasiswa program studi S1 Pendidikan Matematika FKIP Universitas Jambi menunjukkan kemampuan metakognisi yang tergolong dalam kategori sudah berkembang baik yang dinilai berdasarkan skor hasil jawaban mahasiswa untuk setiap proses kemampuan metakognisi. Kemampuan metakognisi mahasiswa dipisahkan menjadi metacognitive awareness, metacognitive evaluation dan metacognitive regulation setiap kemampuan metakognisi akan dinilai berdasarkan jawaban yang ditampilkan oleh mahasiswa. Hasil rangkuman kemampuan metakognisi mahasiswa tersebut dapat dilihat dalam tabel berikut:

Tabel 1. Hasil Ceklis Pemenuhan Kemampuan Metakognisi Mahasiswa Dalam Menjawab

\begin{tabular}{|c|c|c|c|c|c|c|}
\hline Mhs/Mtgns & Mhssw 1 & Mhssw2 & Mhssw 3 & Mhssw 4 & Mhssw 5 & Total \\
\hline $\begin{array}{c}\text { metacognitive } \\
\text { awareness }\end{array}$ & $\checkmark$ & - & - & $\checkmark$ & $\checkmark$ & 4 \\
\hline $\begin{array}{c}\text { metacognitive } \\
\text { evaluation }\end{array}$ & $\checkmark$ & $\checkmark$ & $\checkmark$ & $\checkmark$ & - & $\mathbf{4}$ \\
\hline $\begin{array}{c}\text { metacognitive } \\
\text { regulation }\end{array}$ & - & $\checkmark$ & - & $\checkmark$ & - & $\mathbf{2}$ \\
\hline Total & $\mathbf{2}$ & $\mathbf{2}$ & $\mathbf{1}$ & $\mathbf{3}$ & $\mathbf{1}$ & \\
\hline
\end{tabular}

Berdasarkan tabel 1 dapat dianalisa hasil jawaban soal untuk kemampuan metakognisi ke lima mahasiswa:

1. Mahasiswa 1 dalam menampilkan metacognitive awareness keempat mahasiswa dapat menampilkan dengan baik hanya satu mahasiswa yang tidak menampilkan apa yang dianalisis masalah soal, mahasiswa dapat sadar dengan apa yang akan dilakukan dalam penyelesaian masalah matematika hasil kemampuan ini terlihat berdasarkan jawaban mahasiswa yang mampu menampilkan diketahui dan ditanya masalah soal. Untuk kemampuan metacognitive evaluation ada satu mahasiswa yang tidak bisa menampilkan kemampuan mengevaluasi strategi untuk menyelesaikan masalah, hasil jawaban siswa hanya terlihat sampai pada tahap menganalisis masalah. Dan hanya satu mahasiswa yang mampu menampilkan kemampuan metakognisi sampai kepada kemampuan metacognitive regulation, mahasiswa tersebut dapat menjabarkan hasil jawabannya dan dapat memodifikasi hasil jawabanya sehingga memperoleh jawaban yang sempurna.

2. Mahasiswa 2 dalam menampilkan metacognitive awareness keempat mahasiswa dapat menampilkan dengan baik hanya satu mahasiswa yang tidak menampilkan apa yang dianalisis masalah soal, mahasiswa dapat sadar dengan apa yang akan dilakukan dalam penyelesaian masalah matematika hasil kemampuan ini terlihat berdasarkan jawaban mahasiswa yang mampu 
menampilkan diketahui dan ditanya masalah soal. Untuk kemampuan metacognitive evaluation ada satu mahasiswa yang tidak bisa menampilkan kemampuan mengevaluasi strategi untuk menyelesaikan masalah, hasil jawaban siswa hanya terlihat sampai pada tahap menganalisis masalah. Dan hanya satu mahasiswa yang mampu menampilkan kemampuan metakognisi sampai kepada kemampuan metacognitive regulation, mahasiswa tersebut dapat menjabarkan hasil jawabannya dan dapat memodifikasi hasil jawabanya sehingga memperoleh jawaban yang sempurna.

3. Mahasiswa 3 dalam menampilkan metacognitive awareness keempat mahasiswa dapat menampilkan dengan baik hanya satu mahasiswa yang tidak menampilkan apa yang dianalisis masalah soal, mahasiswa dapat sadar dengan apa yang akan dilakukan dalam penyelesaian masalah matematika hasil kemampuan ini terlihat berdasarkan jawaban mahasiswa yang mampu menampilkan diketahui dan ditanya masalah soal. Untuk kemampuan metacognitive evaluation ada satu mahasiswa yang tidak bisa menampilkan kemampuan mengevaluasi strategi untuk menyelesaikan masalah, hasil jawaban siswa hanya terlihat sampai pada tahap menganalisis masalah. Dan hanya satu mahasiswa yang mampu menampilkan kemampuan metakognisi sampai kepada kemampuan metacognitive regulation, mahasiswa tersebut dapat menjabarkan hasil jawabannya dan dapat memodifikasi hasil jawabanya sehingga memperoleh jawaban yang sempurna.

4. Mahasiswa 4 dalam menampilkan metacognitive awareness keempat mahasiswa dapat menampilkan dengan baik hanya satu mahasiswa yang tidak menampilkan apa yang dianalisis masalah soal, mahasiswa dapat sadar dengan apa yang akan dilakukan dalam penyelesaian masalah matematika hasil kemampuan ini terlihat berdasarkan jawaban mahasiswa yang mampu menampilkan diketahui dan ditanya masalah soal. Untuk kemampuan metacognitive evaluation ada satu mahasiswa yang tidak bisa menampilkan kemampuan mengevaluasi strategi untuk menyelesaikan masalah, hasil jawaban siswa hanya terlihat sampai pada tahap menganalisis masalah. Dan hanya satu mahasiswa yang mampu menampilkan kemampuan metakognisi sampai kepada kemampuan metacognitive regulation, mahasiswa tersebut dapat menjabarkan hasil jawabannya dan dapat memodifikasi hasil jawabanya sehingga memperoleh jawaban yang sempurna.

5. Mahasiswa 5 dalam menampilkan metacognitive awareness keempat mahasiswa dapat menampilkan dengan baik hanya satu mahasiswa yang tidak menampilkan apa yang dianalisis masalah soal, mahasiswa dapat sadar dengan apa yang akan dilakukan dalam penyelesaian masalah matematika hasil kemampuan ini terlihat berdasarkan jawaban mahasiswa yang mampu menampilkan diketahui dan ditanya masalah soal. Untuk kemampuan metacognitive evaluation ada satu mahasiswa yang tidak bisa menampilkan kemampuan mengevaluasi strategi untuk menyelesaikan masalah, hasil jawaban siswa hanya terlihat sampai pada tahap menganalisis masalah. Dan hanya satu mahasiswa yang mampu menampilkan kemampuan metakognisi sampai 
kepada kemampuan metacognitive regulation, mahasiswa tersebut dapat menjabarkan hasil jawabannya dan dapat memodifikasi hasil jawabanya sehingga memperoleh jawaban yang sempurna.

\section{Diskusi}

Kemampuan metakognisi mahasiswa yang dilihat berdasarkan kemampuan metacognitive awareness, metacognitive evaluation dan metacognitive regulation dapat diklasifikasikan berdasarkan setiap kemampuan mahasiswa.

\section{Kemampuan Metacognitive awareness}

Hasil jawaban subjek penelitian dapat terlihat pada gambar berikut:

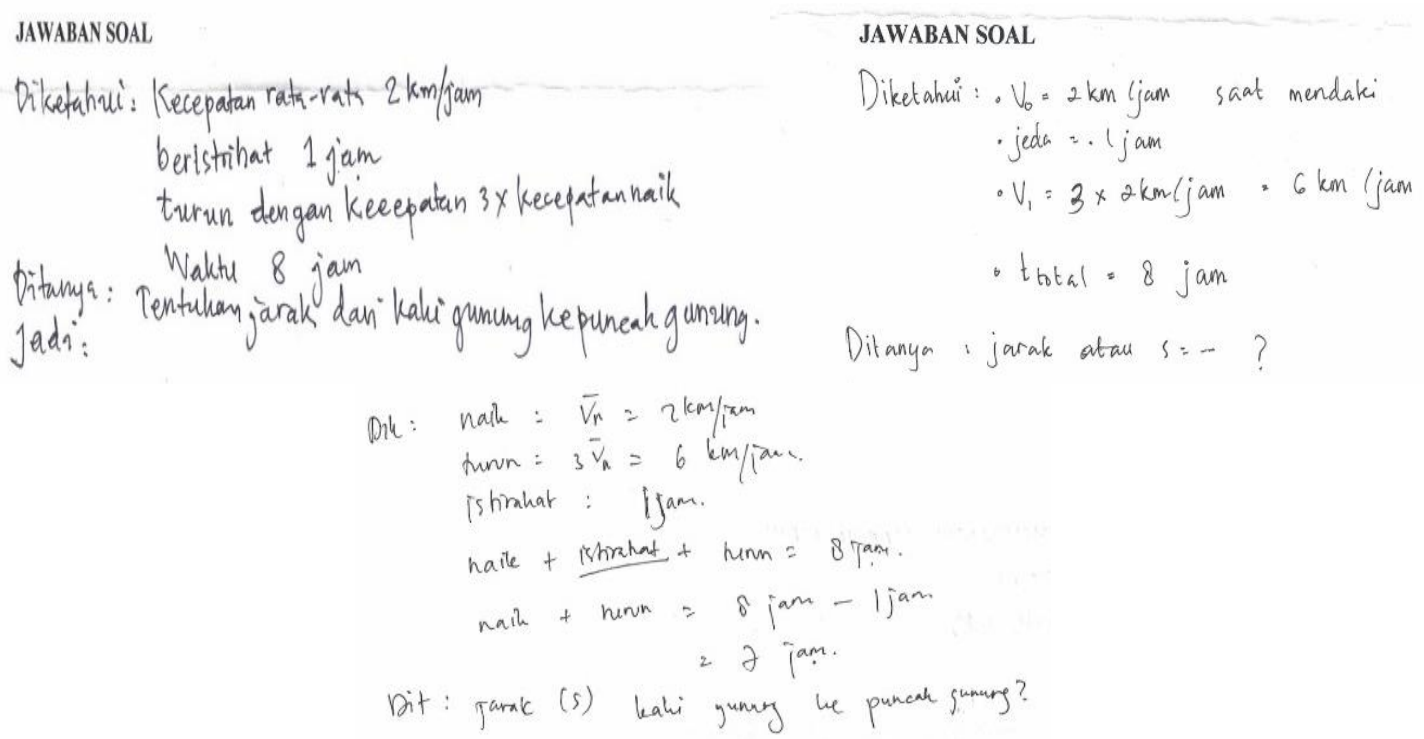

Gambar 2. Hasil Kemampuan Metacognitive awareness

Berdasarkan gambar 2. hasil kemampuan Metacognitive awareness, hasil jawaban tiga mahasiswa sudah mampu sadar dalam proses pemecahan masalah dan telah melakukan proses metacognitive awareness. Hal ini dibuktikan siswa mampu menampilkan apa yang diketahui dan ditanya dalam penyelesaian masalah, langkah yang dilakukan mahasiswa menjelaskan bahwa mahasiswa dapat menganalisa masalah yang harus diselesaikan. Kedua mahasiswa lainnya yang tidak mampu menulis diketahui dan ditanya dalam penyelesaian masalah dinilai belum memiliki kemampuan metacognitive awareness, hal tersebut dikarenakan mahasiswa walaupun memiliki strategi penyelesaian masalah tetapi mahasiswa tersebut tidak bisa menjabarkan hal mendasar tentang analisis penyelesaian masalah.

Hasil penelitian ini sejalan dengan penelitian Novita (2018) yang menyatakan bahwa pemecahan masalah subjek dengan tingkat kognitif tinggi, sedang ataupun rendah dapat berpikir metakognitif dengan mampu sadar membuat perencanaan untuk penyelesain masalah. Hanya saja terdapat subjek yang belum mampu merepresentasikan hasil pemikirannya melalui penulisan dan penjabaran identifikasi masalah. Penelitian lainnya yang dilakukan oleh Saputra (2018) juga menyatakan untuk subjek dengan kemampuan sedang dan rendah cendrung kurang berhasil dalam proses metakognitif, hal ini disebabkan tidak 
cukupnya konsep yang dimiliki.

\section{Kemampuan Metacognitive Evaluation}

Hasil jawaban subjek penelitian dapat terlihat pada gambar berikut:

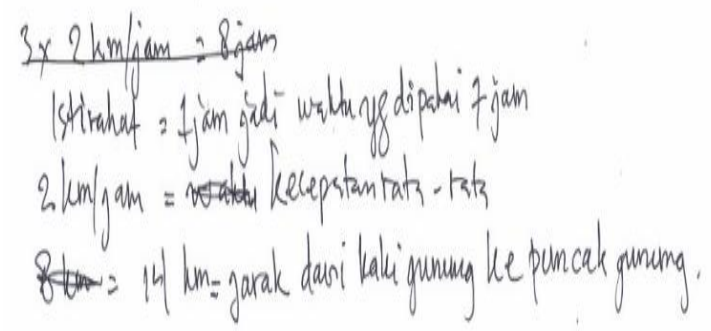

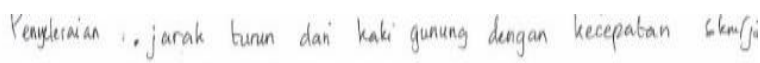

$$
\begin{aligned}
& \text { ithe } 6 \mathrm{~km} \text { jam } \\
& \text { - wakhs yg terhilung tanpa illirahat } 7 \text { jam }
\end{aligned}
$$

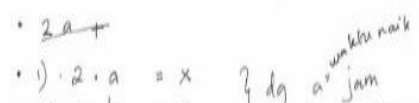

2). $6.6, x \int d g$ b. wakh founen

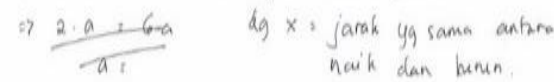
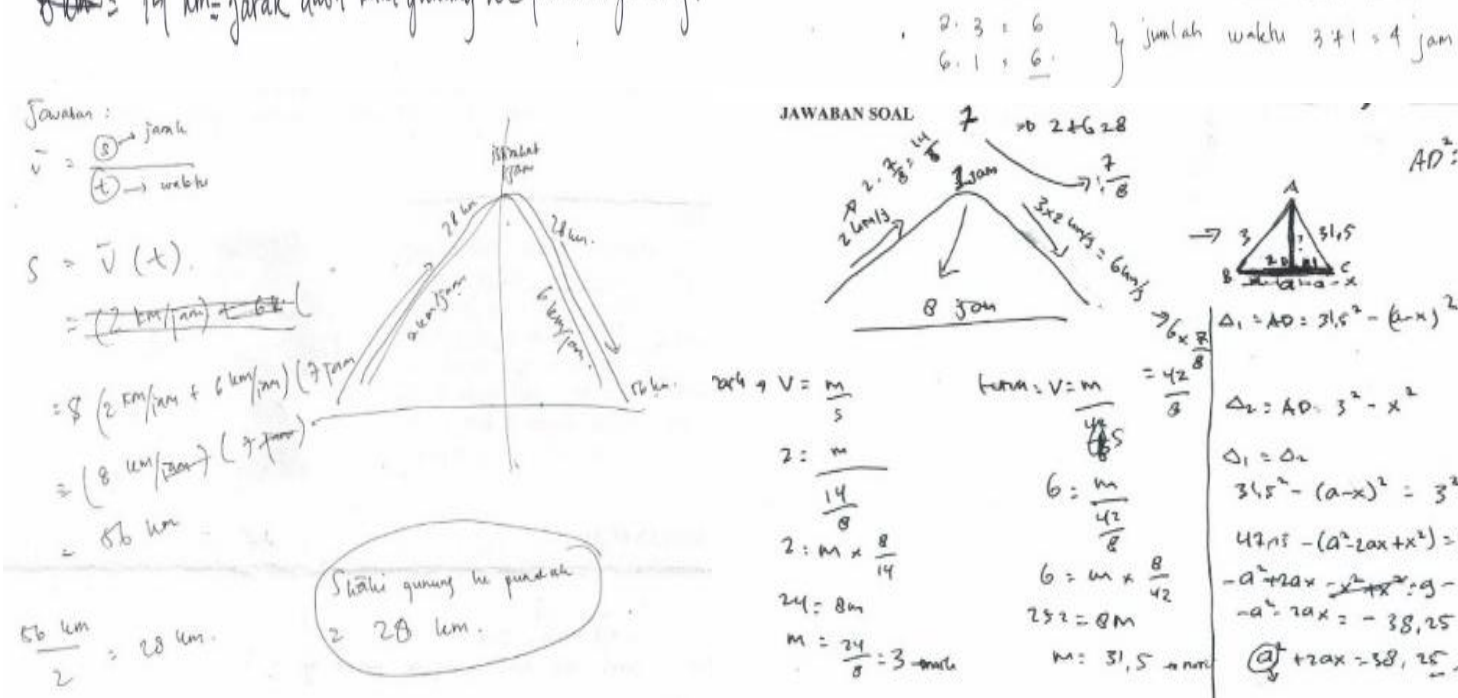

$A D^{2}: A 6^{2}+4$

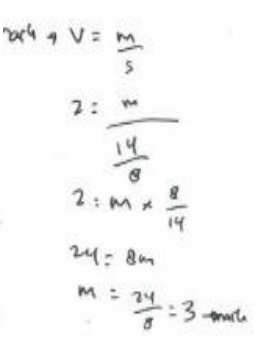

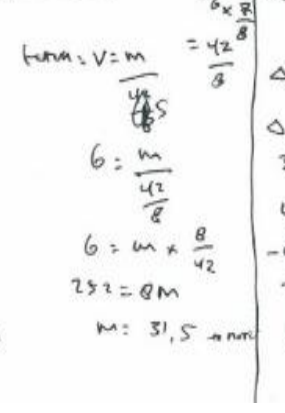

$\Delta_{2}=A_{0} \cdot 3^{2}-x^{2}$
$\Delta_{1}=\Delta_{2}$

$345^{2}-(a-x)^{2}=3^{2}-x^{2}$

$47 n 5-\left(a^{2}-2 a x+x^{2}\right)=9-x$

$-a^{2}+2 a x-x^{2}+x^{2}+9-49,25$

$-a^{2}=2 a x=-38,25$

(a) $+2 a x=38,25=$

Gambar 3. Hasil Kemampuan Metacognitive evaluation

Berdasarkan gambar 3 Hasil kemampuan metacognitive evaluation, hasil jawaban keempat mahasiswa sudah mampu dalam menampilkan metacognitive evaluation yang merujuk pada suatu keputusan dari keefektifan berfikir mahasiswa tentang strategi yang dipilihnya untuk menyelesaikan soal. Keempat mahasiswa dapat menjabarkan strategi yang berbeda dalam menyelesaikan masalah, dari strategi yang sangat sederhana sampai menggunakan sketsa gambar untuk menjelaskan prosedur pemecahan masalah. Hanya seorang mahasiswa yang tidak dapat menampilkan metacognitive evaluation. Kesalahan yang dilakukan oleh mahasiswa ini di karenakan salah penggunaan konsep dalam pemecahan masalah, dan strategi yang digunakan kurang tepat dalam penyelesaian masalah sehingga hasil yang di peroleh tidak tepat. Pernyataan ini dikuatkan dengan hasil penelitian Huda (2018) juga menyatakan bahwa proses kegagalan metakognitif dalam pemecahan masalah matematika juga terjadi pada aktivitas metacognitive evaluation. Proses kegagalan metakognitif pada aktivitas ini terjadi ketika mahasiswa berpikir kembali bagaimana cara pemecahan masalah matematika.

\section{Kemampuan Metacognitive Regulation}

Hasil jawaban subjek penelitian dapat terlihat pada gambar berikut: 


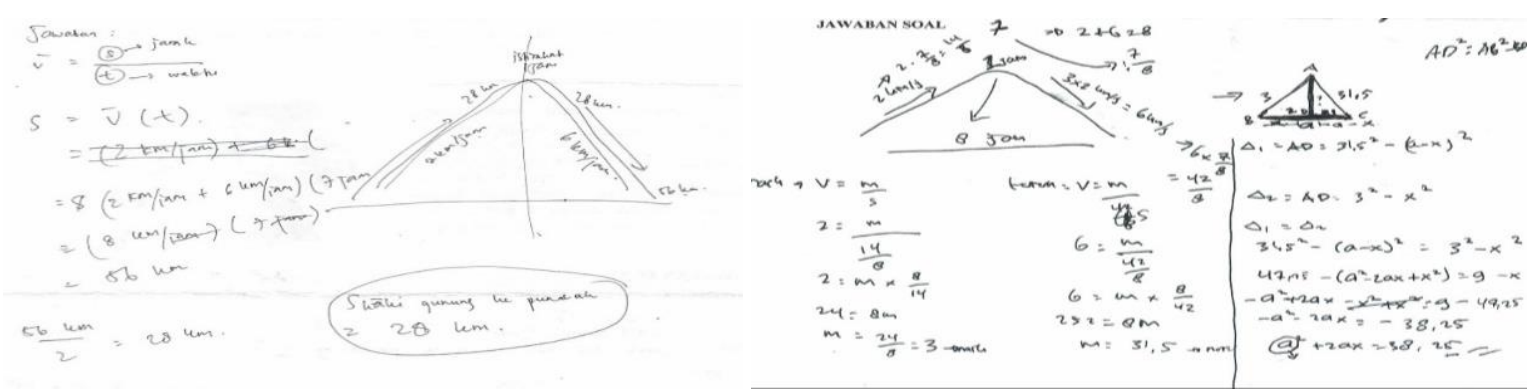

Gambar 4. Hasil Kemampuan Metacognitive regulation

Berdasarkan Gambar 4. Hasil Kemampuan Metacognitive regulation, diketahui bahwa dari lima subjek mahasiswa hanya dua mahasiswa yang mampu dalam menampilkan Metacognitive regulation yang dapat memodifikasi pemikirannya untuk pemecahan masalah. Kedua mahasiswa dapat menjabarkan strategi yang berbeda dalam menyelesaikan masalah dengan menggunakan sketsa gambar untuk menjelaskan prosedur pemecahan masalah. Kemampuan Metacognitive regulation merupakan kemampuan dalam menunjukkan strategi perencanaan, penetapan tujuan, dan memilih strategi pemecahan masalah. Hasil penelitian menunjukkan subjek mengalami kesulitan dalam menampilkan dan memodifikasi pemikirannya serta merancang strategi untuk pemecahan masalah, subjek mengalami kegagalan dalam pemanggilan konsep strategi dalam penyelesaian masalah sehingga hasil jawaban yang diperoleh tidak tepat. Pernyataan ini sejalan dengan pernyataan Patrisius (2019) yang menyatakan bahwa keberhasilan dalam pemecahan masalah matematika membutuhkan optimalisasi pengetahuan yang telah dimilikinya (declarative knowledge, procedural knowledge, conditional knowledge) dan kemampuan merencanakan, memantau, dan mengevaluasi aktivitas pemecahan masalah yang dilakukannya.

\section{KESIMPULAN}

Berdasarkan hasil penelitian dapat disimpulkan bahwa kemampuan metakognisi mahasiswa belum berkembang baik hanya satu orang mahasiswa yang mampu menampilkan kemampuan metakognisi yang sempurna. Rata-rata kemampuan metakognisi mahasiswa dalam menampilkan proses metacognitive awareness telah terlihat dengan mahasiswa mampu menulis diketahui dalam pemecahan masalah, mahasiswa dapat menyadari apa yang akan dilakukan dalam menyelesaikan soal. Dalam menampilkan metacognitive evaluation yang merujuk pada suatu keputusan dari keefektifan berfikir mahasiswa tentang strategi yang dipilihnya untuk menyelesaikan soal hanya empat mahasiswa yang mampu memenuhi kemampuan tersebut, dan untuk metacognitive regulation hanya dua mahasiswa yang dapat memodifikasi pemikirannya untuk pemecahan masalah. Berdasarkan hasil penelitian dapat dilakukan penelitian lanjutan tentang kendala mahasiswa dalam menampilkan kemampuan metakognisi dengan melihat dari pemprosesan informasi dalam penyelesaian masalah yang lebih mendalam.

\section{REFERENSI}

Chairani. 2016. Metakognisi Siswa Dalam Pemecahan Masalah Matematika. Yogyakarta: Deepublish

Creswell, John W. 2012. Research Design Pendekatan Kualitatif, Kuantitatif, dan Mixed. Yogyakarta: 
Pustaka Pelajar.

Desmita. 2014. Psikologi Perkembangan Peserta Didik. Bandung: PT. Remaja Rosdakarya

Huda Nizlel. 2018. Kegagalan metakognitif mahasiswa dalam pemecahan masalah matematika. Universitas Negeri Malang. Program Studi Pendidikan Matematika

Magiera, M.T., \& Zawojewski, J.S. 2011. Characterizations of Social-Based and Self-Based Contexts Associates With Students Awareness, Evaluation, and Regulatin of Their Thinking During SmallGroup Mathematical Modeling.Journal for Research In Mathematics Educarion42(5),486-520

Moleong, L.J. (2013). Metodologi Penelitian Kualitatif. Bandung: PT Ramaja Rosdakarya

Nisvu Nanda Saputra. 2018. Analisis Kemampuan Metakognitif Siswa Sma Dalam Proses Pemecahan Masalah. Aksioma.Jurnal Program Studi Pendidikan Matematika

Panjaitan, B. 2015. Karakteristik Metakognisi Siswa Dalam Memecahkan Masalah Matematika Berdasarkan Tipe Kepribadian. Jurnal Ilmu Pendidikan. Universitas Negeri Malang

Patrisius Afrisno Udil . 2019. Proses Metakognisi dalam Pemecahan Masalah Matematika. Seminar Nasional Pendidikan Matematika. ISBN978-623-7486-01-5

Purnaningsih, N.E \& Siswono, T.Y.E. (2014). Profil Metakognisi Siswa Dalam Memecahkan Masalah Matematika Ditinjau Berdasarkan Tipe Kepribadian Koleris dan Phlegmatis. Jurnal Ilmiah Pendidikan Matematika

Sastrawati, E., Muhammad Rusdi. \& Syamsurizal. 2011. Problem Based Learning, Strategi Metakognisi, dan Keterampilan Berpikir Tingkat Tinggi Siswa, (Online), (http://online.jurnal.unja.ac.id/index.php/pedagogi.pdf, diakses 23 November 2013).

Syaiful. 2011. Metakognisi siswa dalam pembelajaran matematika realistik di sekolah menengah pertama. Edumatica 1(2)

Sugiyono,2016. Metode Penelitian Kuantitatif, Kualitatif dan R\&D. Bandung: PT Alfabet

Tanti Novita. 2018. Metakognisi siswa dalam pemecahan masalah matematika siswa SMA dalam pembelajaran matematika berorientasi etnomatematika Rejang Lebong. Jurnal Pendidikan Matematika Raflesia.Vol. 3 No 1. 